\title{
Fear and Paranoia: A Reading of Zoilo Velaco's Conversations
}

Rhod V. Nuncio

\begin{abstract}
This is a short reader-response interpretation of Zoilo Velasco's poem, Conversations. The interpretive meaning delves into the psychical and philosophical relevance of shadow as fear and eventually as paranoia, which is a defining moment/praxis/element of our human nature. It is not a direct exploration of the formalistic or structural characteristics of the poem but a stimulation and a reflection of other meanings/interpretations which prompted the imagination and experience of the reader/interpreter to bring about a parallel text or an intertext.
\end{abstract}

Keywords: Velasco, Conversations, fear, paranoia

\section{Conversations \\ Zoilo Velasco $^{1}$}

I walk, I run, I stop in great exhaustion.

Who is this shadow who traverses in every side of me?

His form is akin to me, yet why is he faceless?

He is strange, as I am, I guess.

What is strange in him is that he knows me.

Even though I barely know him.

He recognizes me with certainty not much when he looks

At me from the back as when I look at him at his back.

What secret does he have that does not transpire in time,

For even my senses could not decipher the exact moment that

He moves 'til the time that he retires,

Nor my thought could understand the words he utters.

Does he really exist, or is he an illusion?

1 Zoilo Velasco is a lawyer, poet, writer, philosopher and currently works in the Department of Foreign Affairs, Republic of the Philippines. His poem Conversations is one of his many works which remain unpublished. Permission granted by the poet/writer to publish his poem.

(c) 2012 Rhod V. Nuncio http://www.kritike.org/journal/issue 11/nuncio june2012.pdf ISSN 1908-7330

\section{(cc) BY-NO}


Indeed, he simulates me, but for what?

Why?

Or maybe it is I who imitates him.

What if I were a puppet and he, the puppet master?

Am I a slave of this dark creature?

But I decline to think that he is evil for he is

Not afraid of the light.

He is borne by the sun.

The sun which gives light.

The light which gives shadow.

The shadow which gives me.

However, there is the possibility that I am the master,

And he my slave.

Or maybe he is my conscience which bears my

Darkest secrets and no one could know

Because he acts innocently, as I do.

Is he the epitome of my hypocrisy?

Or is he simply my angel of death

Waiting for me to recognize him,

Just like a guardian angel is.

But after I recognize him ... what then...

Should I be afraid?

Should I fear him or should I fear myself?

Maybe he is the silent judge of my actions and visions,

A most stern, formidable and stubborn critic of my mistakes.

What is his name? It can't be "shadow" only.

Other people have shadows too and

He must have his own name.

If shadows are born to all people,

Do they exist and have meaning as my shadow has to me?

Are these shadows brothers? -

Brothers who are united in spirit,

Or brothers who have gone against each other?

It might be the reason why they wear black for

They silently mourn for each other's solitude and ruin.

Is it not possible that this shadow of mine is

The same as the shadows present in others?

They could be the one and the same shadow.

How?

And if so, does it make sense to think

That all people are one and the same, too?

(c) 2012 Rhod V. Nuncio

http://www.kritike.org/journal/issue_11/nuncio june2012.pdf

ISSN 1908-7330 
Why?

Why not?

Are we then brothers who love or brothers who hate and envy each other?

What is the mystery of this obscure reality?

Is he not my only connection with God?

When God created man in his image, is he

Not the "image" that we speak of?

But why is he dark? Is god obscure himself

That is why I hardly know him?

Or is it I who is obscure, and my obscurity

Is that which gives the black color to my shadow?

I want to converse with him but I don't know how.

Why should I even bother to talk to him?

I don't know him, I can't even touch him

But maybe I must.

He might be the only one who knows

Who I am.

\section{A Reader-Response Interpretation ${ }^{2}$}

Nobody can tell the deepest fear one has or bring out certainty from that because of the obscurity that fear ${ }^{3}$ instills in every heart. This is, I presume, what I meant by the shadow. The shadow is the embodiment of our fears - the scariest counterpart of man's sensibility - that transgresses the domain of reason, or more so of rationality. And because reason cannot capture our fear we suddenly find refuge to entertain its bothersome 'existence' in other inexplicable discourse. In

2 Wolfgang Iser, the German literary critic, was the one who defined the phenomenological approach in reading a text. In his ground breaking essay on reader-response criticism, Iser noted that: "It is the virtuality of the work that gives rise to its dynamic nature, and this in turn is the precondition for the effects that the work calls forth. As the reader uses the various perspectives offered him by the text in order to relate the patterns and the 'schematized views' to one another, he sets the work in motion, and this very process results ultimately in the awakening of responses within himself," in "The Reading Process: A Phenomenological Approach,” Modern Criticism \& Theory, ed. by David Lodge with Nigel Wood (Delhi, India: Pearson Education, 2003), 189.

${ }^{3}$ My understanding here of fear is tied up with my reading of the poem. Hence, fear here is defined phenomenologically using reference to my experience and deep reflections. Preconceived scientific/medical/psychoanalytic discussions about fear are bracketed off to give way to my response, my intepretation using stream of consciousness. Sigmund Freud gave lengthy discussions about anxiety and fear. He made three distinctions: realistic anxiety as fear, moral anxiety and neurotic anxiety. Dr. C. George Boeree wrote a comprehensive exposition of Freud's pyschoanalyis in <http://webspace.ship.edu/cgboer/freud.html>.

(C) 2012 Rhod V. Nuncio

http://www.kritike.org/journal/issue_11/nuncio_june2012.pdf

ISSN 1908-7330 
fact, it is true that we need to have a conversation to someone or to something that might or indeed bring us into light. But a conversation with a 'shadow' can be as futile as welcoming fear to reign over us. But who could deny that? It is perhaps in this way that we can defeat futility and fear altogether.

What do I mean by a shadow? By having a shadow? By living with a shadow? It could be well surmised that one characteristic of this phenomenon is its inevitability and its inseparability with us and even with inanimate objects. Yet the shadow is more relevant with human beings, for it so mimics the intricate acts of man. Just like our own fear, for it is also inseparable with human nature, with our 'nature'. Fear as shadow, resides in the imitative consciousness ${ }^{4}$ of man. It imitates our weaknesses, inferiorities and imperfections. That is why we would like to escape and run away from this 'fear's. One fear that I certainly want to hide from is the fear of/from failure. I would say that because I am a dreamer and at the same time a vigilant visionary of life, it is reasonable at the outset to run away from failure. No matter what I pursue, in every direction I go I tend to ignore first the vision of failure because otherwise it will eat me from inside. A vision of failure is a self-destruct mechanism from a dreamer like me. Indeed, I am always optimisticperhaps to the point of being delusionally optimistic! But what surprises me most is that my failure makes me all the more a dreamer. How ironic! Maybe this is how strange I handle my life and yet from this fear I still manage to see the beauty of it all. Maybe my failures are illusions of my dream. Or perhaps just like a 'shadow', it unceasingly binds in me. However whatever it may, I must recognize that this fear of failure is all encompassing, prevalent and powerful. I consider this as a fact of experience. It presents itself to make us spiritually stronger to face the oddities of life.

Because of the ever powerful and all-encompassing nature of fear in man, it proves then how it dictates and controls us in some extreme cases. This is what I might call a seizure of fear that defies yielding or surrender. It insists a calling of sort, an invitation that welcomes every one of us to an open and wide arena of struggle. If one claims that he has won the battle it is only a reaction out from fear-fear that has left anyone asunder to overcome fear because of fear.

The problem now here is to apprehend fear as an entity. It could have been a power personified deflected as the other-half of our personality. Couldn't it be? Like a master-slave relationship, it draws the line between man (fearing subject) and fear (an entity to be feared). And therefore ask: who is the puppet and the puppeteer? Fear could have been just a creation of man's complexity.

\footnotetext{
${ }^{4}$ Imitative consciousness as I used it here in my interpretation of the poem is the act of repeating or recreating fear in our head. It could be a visualization of impending event or a verbal mantra of things to happen that leads to anxiety \& fear.

${ }^{5}$ Psychologists would call this as the "fight or flight" response of persons being confronted by distress or danger.
}

(C) 2012 Rhod V. Nuncio http://www.kritike.org/journal/issue 11/nuncio june2012.pdf ISSN 1908-7330 
There is nothing to be feared about... it is just an illusion or a delusion to think that way. But who can judge that if fear is omnipresent like a Damocles' sword. This kind of fear is highly extrinsic to man. Then man absorbs it internally, mentally. It becomes then a conflict within-maybe from an internal voice, from conscience (or if one believes), from the soul. In one way or the other, if we look deeper and try to find the main cause of this 'conflict', the answer would always be 'fear.' Fear from what? There are many options ... but my answer is this: it is fear from oneself. It may sound (it is!) trivial and paradoxical but this entity called fear is, nothing more, nothing less, the self.

The tendency I think of man is to invent endlessly an imaginary entity to divide him and to reckon all guilt, frustration and whatnot to this 'other' (fear). The more we push this to the limit, the more fear overcomes us and paradoxically, the least we obviously expect for we, just like hypocrites, project a person who is always in his right mind and senses, strong, fiery, unmoved and uncompromising. I mean this 'false projection' is not far for being the most pathetic and most miserable state of man. If fear were a human being or a quasi-being then he could be rejoicing every time we make a divided line. This leads me now to the next and final level of fear: the objectification of fear. Some people argue that they do not know themselves or say specifically, "I do not know what or who I am, and for what I am, unknowingly, capable of." It is believed, in this context, that nobody can grasp a full understanding of oneself not even "himself or "herself. There is a truth in this. Our actions are sometimes unthinkable and even more, irrational for that matter. We may never know why but I presume it is all because of fear. Again, fear emanates internally from man but the problem here is this: if we are so governed by fear then we subsequently become a prey to paranoia. Everything and everyone is a suspect including oneself. In this dilemma, paranoia moves in two ways: (1) following the previous argument, it achieves the disunity of man and fear-man as subject to fear and fear as the pronounced winner in the conflict; (2) it proceeds into a closure of this dualism by becoming fear as man or more precisely as: FEAR BECOMES MAN. I guess you would know what this means in the long run?

But the critical question is this: Is paranoia also inescapable, inevitable?

I guess not... (I think so) Man is gifted with diverse ways to explain his predicaments and to position himself in looking beyond any moment of fear and of unsuspecting paranoia. One thing for sure is that anyone, for any matter or for whatever reason, is still much bigger than his or her fear. For I speak of experience and above all these so and so, I have just played a mockery of it using my pen and paper in this conversation with myself.

Or have I not?

Department of Filipino, De La Salle University-Manila, Philippines

(C) 2012 Rhod V. Nuncio http://www.kritike.org/journal/issue_11/nuncio june2012.pdf ISSN 1908-7330 


\section{FEAR AND PARANOIA}

\section{References}

Boeree, C. George, Personality Theories: Sigmun Freud, in $<$ http://webspace.ship.edu/cgboer/freud.html $>$.

Iser, Wolfgang. "The Reading Process: A Phenomenological Approach," in Modern Criticism \& Theory, ed. by David Lodge with Nigel Wood (Delhi, India: Pearson Education, 2003). 